(C) This is a U.S. government work and not under copyright protection in the U.S.; foreign copyright protection may apply, 2021

DOI: $10.1007 / \mathrm{s} 13592-021-00845-\mathrm{x}$

\title{
Beyond brood: the potential impacts of insect growth disruptors on the long-term health and performance of honey bee colonies
}

\author{
Julia D. Fine ${ }^{1}$ (1), Vanessa CORBY-HarRIs ${ }^{2}$ \\ ${ }^{1}$ Invasive Species and Pollinator Health Research Unit, USDA-ARS, 3026 Bee Biology Rd., Davis, CA 95616, USA \\ ${ }^{2}$ Carl Hayden Bee Research Center, USDA-ARS, Tucson, AZ 85719, USA
}

Received 10 August 2020 - Revised 8 January 2021 - Accepted 4 February 2021

\begin{abstract}
Honey bees are valued pollinators of agricultural crops, and heavy losses reported by beekeepers have spurred efforts to identify causes. As social insects, threats to honey bees should be assessed by evaluating the effects of stress on the long-term health and productivity of the entire colony. Insect growth disruptors are a class of pesticides encountered by honey bees that target pathways involved in insect development, reproduction, and behavior, and they have been shown to affect critical aspects of all three in honey bees. Therefore, it is imperative that their risks to honey bees be thoroughly evaluated. This review describes the effects of insect growth disruptors on honey bees at the individual and colony levels, highlighting hazards associated with different chemistries, and addresses their potential impacts on the longevity of colonies. Finally, recommendations for the direction of future research to identify strategies to mitigate effects are prescribed.
\end{abstract}

agrochemical/Apis mellifera / insecticide/ diflubenzuron / methoxyfenozide/ juvenile hormone/ ecdysone/ risk assessment

\section{INTRODUCTION}

As managed pollinators, honey bees contribute significantly to the production of agricultural crops throughout the world, and countries including the USA have come to rely upon their services to sustain national food security (Southwick and Southwick 1992; Aizen et al. 2008; Calderone 2012). However, since 2006, beekeepers have been reporting heavy annual losses to managed populations (vanEngelsdorp et al. 2009; Kulhanek et al. 2017; Brodschneider et al. 2018). These losses have placed a financial strain on beekeepers, who must expend more resources to replace their failed colonies (DeGrandi-Hoffman et al. 2019). It is predicted that continued losses

Corresponding author: J. D. Fine, Julia.fine@usda.gov Handling editor: Monique Gauthier will result in food shortages due to the limited number of bee colonies in contrast with the agricultural acreage of pollination-dependent crops required to feed expanding human populations (Aizen et al. 2008; Aizen and Harder 2009). For this reason, identifying and mitigating risk scenarios to honey bees is critical.

Four major causative factors have been identified as contributors to honey bee population declines, including exposure to infectious pathogens, parasite infestations, poor quality or limited nutritional resources, and exposure to agrochemicals (Spivak et al. 2011; Goulson et al. 2015). This review will address exposure to agrochemicals, focusing on insect growth disruptors (IGDs), a pesticide class that is known to affect pathways associated with insect growth and development (Pener and Dhadialla 2012). While the effects of IGDs on immature insects are fairly well 
understood (Wright 1976; Dhadialla et al. 1998; Tunaz and Uygun 2004), effects on adult insects are discussed less frequently. This review will cover two broad categories of IGDs, chitin synthesis inhibitors (CSI), and insect hormone mimics (IHM), examining their effects on honey bees and discussing gaps in the current literature relating to the effects of IGDs on honey bee reproduction and colony performance. Based on the summary of the literature, mode of pesticidal action, and the current understanding of honey bee social biology, the impacts of IGDs beyond brood loss, and their potential to impact colony-level performance will be discussed. Finally, future directions for investigative work that may lead to the identification of mitigation strategies will be recommended.

\section{IGDS AND HONEY BEES}

The term IGD refers to a broad class of chemicals that disrupt insect growth, development, and reproduction (Pener and Dhadialla 2012) by acting on the insect endocrine system to interfere with metamorphosis and developmental processes (Williams 1967; Hoffmann and Lorenz 1998; Jindra and Bittova 2020) or by acting as chitin synthesis inhibitors to impair the formation of new cuticle (Grosscurt 1978; Cutler and Scott-Dupree 2007; Matsumura 2010). Because of their selectively lethal activity towards immature insects and their low lethality to beneficial adult insects such as pollinators, IGDs are often considered lower risk relative to other more traditional chemistries such as neurotoxins (Wright 1976), and they are frequently preferred over other insecticides in agricultural settings where beneficial insects are present. One particularly high-profile example of this use pattern is in blooming almond orchards in California (Mullin et al. 2016; CalDPR 2019; Wade et al. 2019).

The almond bloom in California is the largest pollination event in the world, requiring two thirds of the managed colonies in the USA to be transported, often across thousands of miles, to orchards in the Central Valley where they remain for weeks during the blooming period. It is estimated that the almond production industry adds over $\$ 20$ billion to the economy of California
(Sumner et al. 2016), and it has become a critical event for commercial beekeepers, who rely upon the premium fee almond growers pay for hive rentals during almond bloom (Rucker et al. 2012). Part of the reason this premium is offered is the stress on colonies associated with pollination events (Ahn et al. 2012; Zhu et al. 2014; Cavigli et al. 2016; Simone-Finstrom et al. 2016).

During the bloom period, growers often apply various agrochemicals to control insects and plant pathogens. Tank mixtures typically contain IGDs, fungicides, and adjuvants (Mullin et al. 2016; Wade et al. 2019) and are applied at night when bees are not actively foraging. However, the residues of these agrochemicals persist in the environment. Foraging bees encountering these residues in pollen, nectar, and other relevant matrices can experience negative effects by direct exposure, but foragers may also return to the colony with the contaminated resources (Mullin et al. 2010; Traynor et al. 2016). This can result in a systemic exposure scenario in which other members of the colony such as the nurse bees, reproductive castes, and developing brood may be exposed (Berenbaum and Liao 2019). In recent years, some beekeepers have reported colony loss characterized by heavy brood loss following almond pollination (Pollinator Stewardship Council 2014). While other factors likely contribute to this phenomenon, including exposure to fungicides (Mao et al. 2017), adjuvants (Mullin et al. 2016), and pathogens (Cavigli et al. 2016; Fine et al. 2017a), IGD toxicity remains a likely explanation due to their known effects on immature insects. While the effects on developing brood may be the most obvious sign of potential IGD poisoning in a colony, beekeepers should be aware of the potential effects these chemistries may be exerting on other members of the colony, which may be more difficult to diagnose and treat (Figure 1).

\section{CHITIN SYNTHESIS INHIBITORS}

Chitin is a critical component of insect cuticle, but it also has functions in insects that are often overlooked. For example, chitin is a major component of the peritrophic membrane (PM) lining the insect gut. The PM is critical to ensuring nutrient absorption while protecting insects from 


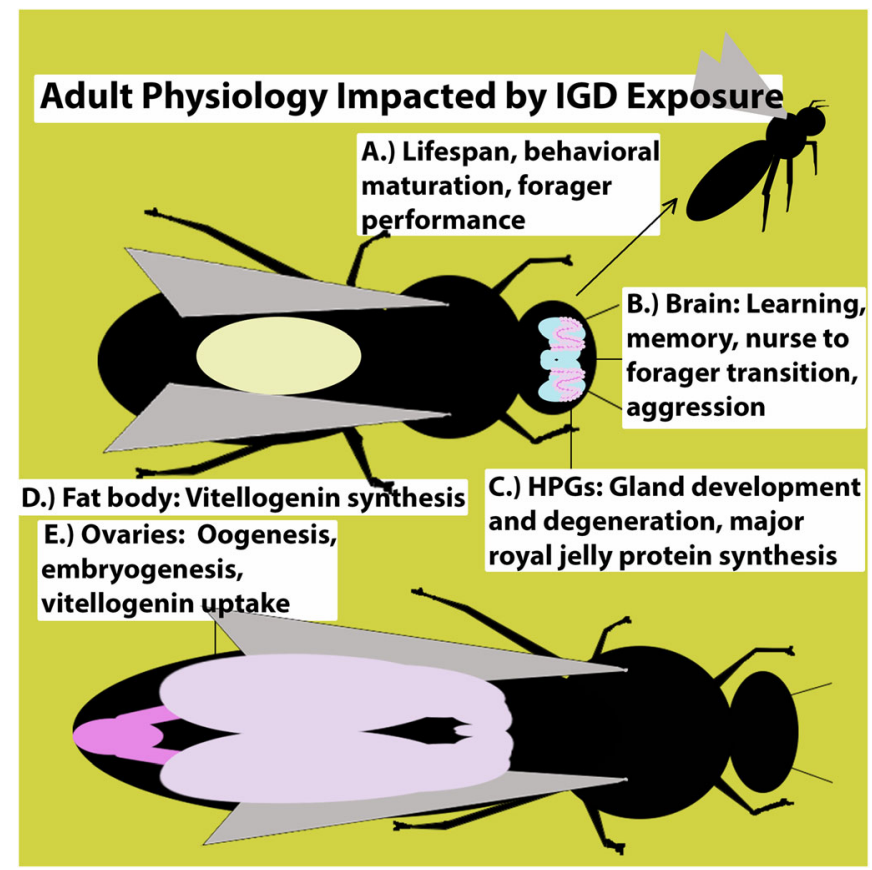

Figure 1 IGD exposure has been found to affect numerous aspects of adult worker and queen physiology and behavior in the following ways: A.) accelerating behavioral maturation (Jaycox et al. 1976; Jaycox et al. 1974; Robinson 1985), reducing lifespan, and impairing foraging performance of worker honey bees (Perry et al. 2015; Chang et al. 2015; Fisher et al. 2018; Meikle et al. 2019); B.) impairing learning and memory (Abramson et al. 2004) and increasing aggressive responses to stimuli (Robinson 1985); C.) HPG development and royal jelly protein production (Gupta and Chandel 1995; Chen et al. 2016); D.) vitellogenin synthesis in the fat body and uptake into other tissues (Pinto et al. 2000); E.) oogenesis and embryogenesis (Thompson et al. 2005a; Milchreit et al. 2016; Fine 2020). This figure was created using Photoshop CC 2021 (Adobe Inc., San Jose, CA).

invading pathogens (Merzendorfer and Zimoch 2003). In honey bee larvae, the PM acts as a barrier to prevent infection with the American Foulbrood causative agent, Paenibacillus larvae. Once the PM is fully formed $48 \mathrm{~h}$ after larval eclosion (Davidson 1970), larvae have increased immunity to infection by this pathogen (Brødsgaard et al. 1998; Yue et al. 2008). Similarly, chitin is a component of cocoons that holometabolous insects, including honey bees, produce during pupation (Moussian 2019). The residual cocoon material left after adult eclosion is thought to increase homeostasis in the colony by buffering humidity (Ellis et al. 2010).

Chitin synthesis inhibitors (CSIs) are IGDs designed to target and disrupt pathways associated with the formation of insect cuticle (Matsumura 2010). Typically, this results in the mortality of immature insects due to an unsuccessful molt following oral or topical exposure. However, CSIs can also affect oviposition (Moffitt et al. 1983; Cutler et al. 2005) and embryogenesis (Henzell et al. 1979; Medina et al. 2002) in reproductive adult insects. Due to their low adult lethality, CSIs are often applied to blooming crops, though this practice is discouraged when bees are actively foraging due largely to their toxicity to honey bee brood. Currently, the CSI diflubenzuron remains one of the most commonly applied agrochemicals in California almond orchards during the weeks when honey bee colonies are foraging (CalDPR 2019; Wade et al. 2019).

While the disruption of chitin formation may not have well-established effects on adult worker honey bees, exposure to CSIs can be lethal to immature honey bees as they develop from larvae to pupae and adults (Fine et al. 2017b; Wade et al. 2019). Similarly, chitin formation is critical 
during embryogenesis when the first instar larval cuticle is formed (Moussian et al. 2005; Moussian 2019), and chitin is a major component of insect egg chorion. A thin or poorly formed egg cuticle could result in detrimental effects including the dehydration of the embryo (Jacobs et al. 2013), impaired respiration, and hatching (Hinton 1969). Maternal exposure to CSIs has been observed to have embryotoxic effects in insects (Henzell et al. 1979; Medina et al. 2002), yet surprisingly few studies have explored this as a possibility in honey bees (Milchreit et al. 2016; Chen et al. 2016; Fine et al. 2017b; Fine 2020).

\section{INSECT HORMONE MIMICS}

Insect hormone mimics (IHM) are compounds that act on the insect endocrine system to disrupt the process of insect metamorphosis (Wright 1976; Hoffmann and Lorenz 1998; Jindra and Bittova 2020). Like CSIs, IHMs result in the mortality of immature insects by interfering with the hormone balance required for successful ecdysis, often blocking molting or triggering it prematurely, resulting in death (Dhadialla et al. 1998; Retnakaran et al. 2003; Jindra and Bittova 2020). The most common signaling pathways targeted by IHMs are those normally mediated by juvenile hormone $(\mathrm{JH})$ and ecdysone. Despite the established role of these pathways in mediating critical aspects of adult bee physiology and behavior (Gilbert et al. 1980; Bloch et al. 2013; Pandey and Bloch 2015), IHMs exhibit low lethal toxicity to adults and are widely considered to be safer to beneficial insects (Dhadialla et al. 1998). Because of this, the use of IHMs such as the ecdysone agonist, methoxyfenozide, or the $\mathrm{JH}$ analogue, pyriproxyfen, in blooming, beepollinated crops like almonds is encouraged relative to other, more acutely toxic pesticides.

In immature insects, growth and development are regulated by JH and ecdysteroids (Weir 1970; Nijhout 1998; Smagghe 2009; Riddiford 2012). Generally, JH titers in the hemolymph of immature insects are higher between molting periods, but dip when the larva has reached a critical weight, triggering ecdysone levels to rise and induce a molt (Mirth et al. 2014). This interaction is more complex in the latter stages of holometabolous insect development, when JH tightly regulates the action of ecdysone and the timing of the pupal and adult molt (Hartfelder 2000; Zhou and Riddiford 2002; Dubrovsky 2005). Interfering with this process, either by administering artificial hormone analogues or compounds that antagonize their production, produces deleterious effects in immature insects. Although the sublethal effects of IHMs on developing brood are not well studied, JH and ecdysteroid levels influence ovary development and caste differentiation in immature honey bees (Hartfelder et al. 1995; Capella and Hartfelder 1998; Elekonich et al. 2003; Amdam et al. 2010), and the presence of ecdysteroids in honey bee queen ovary tissue and in embryos suggests a role in embryogenesis (Feldlaufer et al. 1986; Mello et al. 2014). Therefore, it is likely that exposure to low levels of IHMs during embryogenesis and subsequent development could influence the reproductive potential, health, and physiology of honey bee queens and workers.

In adult insects, $\mathrm{JH}$ regulates oogenesis as well as numerous behaviors associated with reproduction (Park et al. 1998; Shu et al. 1998; Webb et al. 1999), and JH titers are typically positively correlated with vitellogenin (Vg) levels (Hagedorn and Kunkel 1979; Bellés 2005). However, in honey bees, this relationship is inverse. Young honey bee workers have higher hemolymph titers of $\mathrm{Vg}$ and low levels of $\mathrm{JH}$, but as workers age and transition to foraging tasks, $\mathrm{JH}$ levels rise and Vg declines (Robinson 1987; Robinson et al. 1991; Pinto et al. 2000). In mated queens, JH levels are generally low when the queen is engaged in oogenesis, but are higher in unmated, previtellogenic queens or queens that are prevented from laying by caging, and $\mathrm{JH}$ suppresses $\mathrm{Vg}$ synthesis and uptake into tissues (Pinto et al. 2000; Wegener et al. 2013). The antioxidant properties of $\mathrm{Vg}$ and its relationship with $\mathrm{JH}$ are thought to be important regulators of honey bee lifespan (Amdam et al. 2004), as evidenced by the senescence of worker bees when $\mathrm{JH}$ levels are high and the longer lifespan of queens, whose $\mathrm{Vg}$ levels remain high relative to workers for at least a year (Corona et al. 2007) or while she is actively laying eggs (Wegener et al. 2013). In worker bees, JH also regulates behavioral 
maturation, and increases in $\mathrm{JH}$ titers result in increased aggression and the onset of foraging behaviors (Robinson 1985).

Similar to JH, ecdysteroids influence aspects of adult insect behavior and physiology including ovariole development, longevity, circadian rhythm, and learning behaviors (Simon et al. 2003; Ishimoto et al. 2009; Ishimoto and Kitamoto 2010; Ables et al. 2016). In adult honey bees, ecdysteroids are primarily synthesized by the ovarian tissue and are involved in oocyte maturation and embryogenesis (Robinson et al. 1991; Amdam et al. 2010; Wegener et al. 2013). In worker honey bees, ecdysteroids are known to affect hypopharyngeal gland (HPG) development and protein synthesis (Corby-Harris et al. 2016, 2019; Winkler et al. 2018), suggesting they be involved in nutrient signaling and behavioral maturation. Additionally, ecdysteroids influence brain development and aversive learning in workers (Geddes et al. 2013), further supporting their role in regulating behavior.

Because insect development is regulated by the hormone pathways targeted by IHMs, these IGDs are often highly toxic to immature insects. However, while disrupting hormonal pathways in adult insects may not be deleterious, insect endocrine signaling regulates numerous behaviors and aspects of physiology in adult insects. Without evaluation, it should not be assumed that nonlethal doses do not have profound impacts on adult honey bees, and by extension, on the entire colony.

\section{EFFECTS OF IGDS ON HONEY BEE REPRODUCTION}

By far, the most well-characterized effects of IGDs on honey bees relate to reproduction (Figure 2), specifically, their detrimental effects on brood rearing (last reviewed by Tasei 2001). CSIs are highly toxic to honey bee brood in laboratory (Fine et al. 2017b; Wade et al. 2019) and colony-level experiments (Barker and Waller 1978; Emmett and Archer 1980; Thompson et al. 2005a; Fine et al. 2017b), so much so that the CSI triflumuron was once suggested as a means to control Varroa mite infestation by completely disrupting the brood cycle of a colony (Herbert et al. 1986). In this study, free flying colonies fed a solution of $150 \mathrm{ppm}$ triflumuron reared no brood following the treatment, but 22 days later, the colony appeared to have recovered. Interestingly, in caged colonies, triflumuron did not disrupt queen egg laying, but when placed in foster colonies, the eggs were removed by workers, suggesting they were not viable. Similar findings have been reported for the CSIs diflubenzuron and novaluron, which can both disrupt colony-level brood production at high enough doses (Barker and Waller 1978; Thompson et al. 2005a; Fine et al. 2017b). The deleterious effects on honey bee brood caused by exposure to IHMs have been documented in both laboratory (Zufelato et al. 2000) and field experiments (Chen et al. 2016), and sublethal effects on bees that survive larval exposure including wing deformities and reduced lifespan have been described (Fernandez et al. 2012; Fourrier et al. 2015). In addition to directly affecting brood, the modes of action of IHMs suggest that they are likely to affect aspects of adult physiology and behavior that contribute to brood rearing capacity. For example, JH and ecdysteroids may influence $\mathrm{Vg}$ synthesis and uptake in adult queen and worker bees (Barchuk et al. 2002; Wegener et al. 2009, 2013), which could, in turn, influence the production of royal jelly and brood food by the HPGs and oocyte maturation (Amdam et al. 2003; Seehuus et al. 2007). Indeed, the JH analogue, pyriproxyfen, inhibits $\mathrm{Vg}$ synthesis in worker bees (Pinto et al. 2000) and decreases royal jelly production at the colony level (Chen et al. 2016). In contrast, chronic consumption of an ecdysone agonist, methoxyfenozide, has been shown to affect HPG size in 2-week-old worker bees, resulting in larger glands relative to similarly aged controls (Fine 2020). In the field, methoxyfenozide exposure resulted in decreased forager activity, which could be a consequence of delayed or altered behavioral maturation (Meikle et al. 2019).

While the majority of experiments do not specifically assess the effects of IGDs on honey bee queen performance, a small number of studies have addressed the possibility. Barker and Waller (1978) observed that colonies treated with diflubenzuron had more eggs present relative to control following a 40-day exposure period, which was attributed to a transovarial effect on 


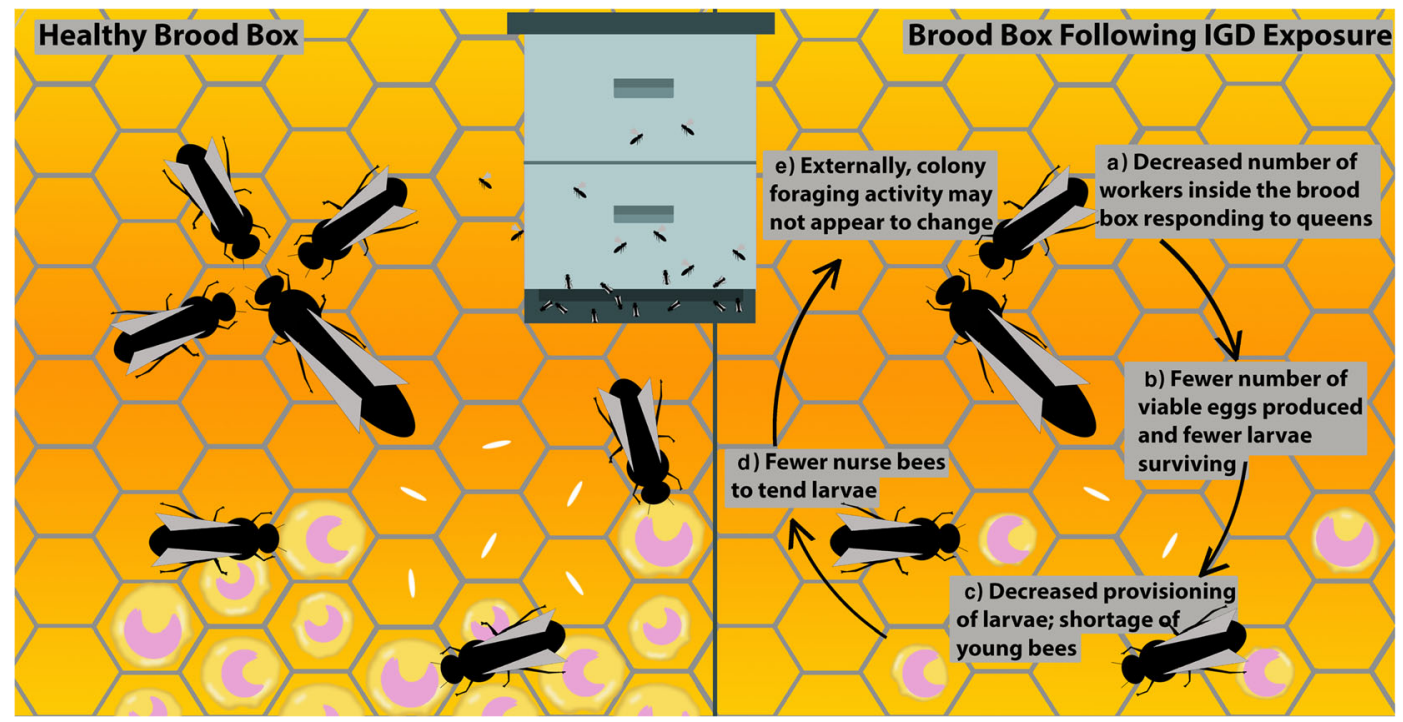

Figure 2 The potential effects of IGDs on intra-colony dynamics. Inside a healthy colony (left), brood rearing activities are sustained by a productive queen and a population of young worker bees acting as nurses and queen attendants. Inside an IGD-exposed colony (right), these activities can be compromised due to A.) a decreased number of available and responsive queen attendants due to accelerated behavioral maturation (Perry et al. 2015), B.) fewer viable eggs produced by queens (Milchreit et al. 2016; Chen et al. 2016) and fewer surviving larvae (Zufelato et al. 2000; Thompson et al. 2005; Chen et al. 2016; Fine et al. 2017b), and C.) decreased provisioning of larvae due to D.) fewer nurse bees present in the colony and/or decreased vitellogenin synthesis (Pinto et al. 2000; Perry et al. 2015; Chen et al. 2016). This figure was created using Photoshop CC 2021 (Adobe Inc., San Jose, CA).

embryo viability, resulting in a high number of inviable eggs remaining in the colony, or a compensatory increase in egg production to account for the loss of brood due to the diflubenzuron treatment. By closely monitoring and manipulating queens in full-sized colonies, Chen et al. (2016) found a negative effect on the rate of first instar eclosion from eggs laid under exposure to JH analogue pyriproxyfen. Using a targeted, cross-fostering approach, Milchreit et al. (2016) demonstrated the transovarial toxicity of a $\mathrm{JH}$ agonist to honey bees by showing that maternal exposure to fenoxycarb negatively affects first instar eclosion and survival to adult eclosion. Thompson et al. (2005) reported an effect of the same JH agonist on mating success and egg production, though the viability of the eggs produced during this experiment was not specifically assessed. In the same study, sperm counts of mature drones reared under exposure to CSIs and IHMs were assessed. No significant differences were detected among treatments, though the availability of drones from colonies treated with the CSI diflubenzuron and IHM fenoxycarb was negatively affected by the treatment related heavy brood loss. The CSI novaluron has also been found to disrupt brood production in honey bee colonies and studies on honey bees (Fine et al. 2017b) and alfalfa leaf-cutter bees (Hodgson et al. 2011; Pitts-Singer and Barbour 2017) suggest it may have a dramatic effect on embryogenesis. In a semi-field-level study performed on nucleus colonies, it was demonstrated that exposure to $18.6 \mathrm{ppm}$ novaluron for a period of 7 days resulted in no apparent decreases in queen egg laying rates, but no evidence of hatching could be seen in the colonies for up to 21 days following the treatment (Fine et al. 2017b). In a recent experiment involving the use of specialized cages to quantitatively track queen egg laying, no effect on the quantity of eggs produced was documented when queens were exposed through worker diet to novaluron, diflubenzuron, or methoxyfenozide at $10 \mathrm{ppm}$, 
though a decrease in egg eclosion rate was observed for all three treatments (Fine 2020).

\section{EFFECTS OF IGDS ON WORKER BEHAVIOR AND PHYSIOLOGY}

Despite the low lethal toxicity of IGDs to adult honey bees, sublethal effects have been reported, including impaired memory and learning (Abramson et al. 2004) and decreased weight gain and HPG development (Gupta and Chandel 1995). In addition, exposing foragers to certain IGDs at tank mix concentrations reportedly decreases longevity (Fisher et al. 2018). One of the most well-known effects of IGDs is the accelerated behavioral maturation caused by exposure to JH mimics like methoprene, pyriproxyfen, and fenoxycarb (Jaycox et al. 1974; Robinson 1985, 1987). This phenomenon, known as precocious foraging, in which workers leave the colony to forage at an earlier age, ultimately shortens worker lifespan (Jaycox et al. 1974) and reduces the population of young worker bees inside the colony that support colony-level reproduction (Perry et al. 2015). Bees that precociously transition to forager tasks are not as efficient and do not forage for as long as their naturally aged counterparts (Perry et al. 2015; Chang et al. 2015).

Conversely to $\mathrm{JH}$, the role of ecdysteroids and ecdysteroid agonists is less well-understood, though there is a growing body of evidence suggesting that like $\mathrm{JH}$, ecdysteroids influence behaviors in adult bees (Pandey and Bloch 2015). The ecdysone agonist methoxyfenozide is one of the most commonly used IGDs in blooming almonds. Despite its selective activity for lepidopteran pests (Dhadialla et al. 1998), methoxyfenozide has been shown to influence colony thermoregulation and foraging activity (Meikle et al. 2019). At a higher dose than Meikle et al., increased HPG size has been reported (Fine 2020), similar to what has been documented in workers following treatment with 20-hydroxyecdysone (Corby-Harris et al. 2016).

\section{M E T A B OL I C COST S OF DETOXIFYING IGDS}

Even if IGDs are specific to their target pests (Dhadialla et al. 1998), detoxification itself may be costly if it diverts energy away from other metabolic processes or reproduction (Kliot and Ghanim 2012). Numerous examples show that populations selected for resistance to humanmade and plant defense chemicals have reduced fitness (reviewed in (Després et al. 2007; Kliot and Ghanim 2012), but see (Ffrench-Constant and Bass 2017)). Honey bees detoxifying plant- and human-made chemicals do seem to incur metabolic costs. Larval and adult bees exposed to the plant defense compound nicotine and the neonicotinoid imidacloprid show increased expression of genes and proteins related to energy metabolism (Derecka et al. 2013; du Rand et al. 2017), implying a degree of energetic stress. We are unaware of similar studies using IGDs as a chemical stressor, and so it is unclear whether detoxification of this class of pesticide induces metabolic costs. Because honey bees have a limited detoxification repertoire (Claudianos et al. 2006), the same enzymes that detoxify plant defense compounds and neonicotinoids in a metabolically costly manner may work to detoxify IGDs and indirectly reduce bee health.

\section{EFFECTS OF IGDS ON COLONIES}

Of the effects of IGDs on brood, workers, and queens, brood loss is the most widely discussed consequence of IGD poisoning. Certainly, brood loss can drastically affect the longevity and performance of a colony, particularly if it is sustained and if the colony is subjected to additional stressors. However, changes to adult behavior like precocious foraging caused by IGD exposure may be a contributor to colony declines over time, even more so than heavy brood loss. Thompson et al. (2005) attempted to study this phenomenon by exposing colonies to fenoxycarb and other IGDs in sucrose at maximum tank mix concentrations for 1 week in the summer and tracking colony performance through the winter to the subsequent spring. Following treatment, declines in brood production were observed, adult populations were low after winter, and the colony build-up in the spring was delayed relative to control and other IGD treatments. The authors hypothesized that this slow build-up was due to the heavy brood loss and potentially a 
heavy loss of adult populations caused by precocious foraging. Using a modeling approach, it was estimated that precocious foraging caused by exposure to $\mathrm{JH}$ analogues like fenoxycarb can have a more pronounced detrimental effect on colony longevity than brood loss (Thompson et al. 2007).

Precocious foraging occurs in response to multiple different categories of stress (Bordier et al. 2017), including nutritional deficits (Free 1961; Schulz et al. 1998; Janmaat and Winston 2000), disease (Higes et al. 2008; Woyciechowski and Moroń 2009; Goblirsch et al. 2013; Benaets et al. 2017), and exposure to agrochemicals (Thompson 2003; Colin et al. 2019). However, evidence of colony-level effects of stress-induced precocious foraging can take months (Thompson et al. 2005; Higes et al. 2008; Khoury et al. 2011; Perry et al. 2015), as the colony may initially be able to buffer the effects of population loss through brood rearing. For this reason, long-term monitoring of colonies after exposure to IGDs may be necessary to detect effects due to behavioral shifts.

Similar to the potentially large-scale effects caused by effects on adult workers, effects on honey bee queens may be far more consequential to the health and performance of the colony over time than effects on honey bee brood. Following exposure to an IGD, brood rearing should recover once a colony has been cleared of residual IGDs in colony matrices. However, effects on honey bee queens could be much longer lasting. Unlike worker bees that typically survive for roughly 4 weeks during the active spring, summer, and fall months (Winston 1991), honey bee queens can live for multiple years, during which time they are solely responsible for producing fertilized eggs inside a honey bee colony (Page and Peng 2001). In commercial operations, beekeepers typically requeen annually as a prophylactic measure or when brood pattern becomes noticeably irregular (Lee et al. 2019). However, the indicators of queen failure could easily be missed, particularly in large-scale operations where beekeepers cannot thoroughly inspect brood frames in every colony, and often the indications come too late, when colony populations decline precipitously due to a shortage of emerging adult bees to replace the aging forager population. One further complication is the recent finding that brood pattern is not always a reliable indicator of queen quality (Lee et al. 2019), highlighting the need for more research to investigate the factors that contribute to queen performance and identify more reliable diagnostic metrics.

Queen failure, as defined by the loss of the queen or impaired queen performance, has been identified by beekeepers as one of the major factors contributing to colony loss (vanEngelsdorp et al. 2013). Negative effects on queen survival, health, and performance have been reported for queens exposed to agrochemicals, both during development (DeGrandi-Hoffman et al. 2013; Williams et al. 2015; Walsh et al. 2020) and as adults (Thompson et al. 2005; Milchreit et al. 2016; Chen et al. 2016; Fine et al. 2017b; Fine 2020). Despite this, the effects of maternal agrochemical exposure in honey bees are seldom examined or considered when evaluating risk scenarios to honey bee colonies. Part of the reason for this could be an underlying assumption that honey bee queens are insulated from the effects of agrochemical exposure on colonies (Purdy 2015). This assumption stems from the concept of a "shared stomach," (Sponsler and Johnson 2017; Schmickl and Karsai 2017) which describes the movement of resources within a colony. This movement involves forager collection of resources, the processing and storing of resources by hive bees, consumption by nurse bees and older larvae, and the conversion of these nutrients into the glandular secretions that make up the queen and larvae's diet (Purdy 2015). At each step during the handling and processing, some degradation of the agrochemical residues is expected to occur through metabolism or environmental transformation. Indeed, there is evidence that even foragers transporting nectar back to the colony in their crop may begin the process of metabolizing xenobiotic chemicals (Vannette et al. 2015). Residues of agrochemicals detected in royal jelly are typically much lower than levels in worker diet (Johnson and Percel 2013; DeGrandi-Hoffman et al. 2015; Böhme et al. 2018), suggesting that nurse bees are capable of efficiently metabolizing agrochemicals in a manner that protects young larvae and queens from exposure to high levels of many agrochemicals. However, even pesticides that do not persist at detectable levels in diet may pose risks to developing brood and reproductive castes through persistence in wax (Wu et al. 2011) or by 
altering the physiology and immune function of their worker caretakers (DeGrandi-Hoffman et al. 2015; Zaluski et al. 2020). As reviewed here, field- and semi-field-level experiments have demonstrated that feeding colonies IGDs can result in brood loss, suggesting that they are not always adequately protected from IGD exposure by the "shared stomach" at the doses studied. Honey bee queens are similarly provisioned by workers with glandular secretions (Crailsheim 1992), and indeed, effects of IGDs on queens have been documented (Thompson et al. 2005; Milchreit et al. 2016; Chen et al. 2016). Given the importance of honey bee queen quality to the longevity and productivity of colonies, it is imperative that the potential effects of IGDs on queens be more thoroughly investigated.

\section{FUTURE DIRECTIONS}

Recently, it has been suggested that endocrine disruption by agrochemicals should be considered a critical aspect of risk assessment for pollinators (Christen et al. 2018). The current research pertaining specifically to IGDs supports this, highlighting the need for more detailed assessments of how IGDs impact honey bee reproduction and behavior. Honey bees regularly encounter IGDs in their foraging environments (Mullin et al. 2010; Traynor et al. 2016), yet, for many chemistries, effects on critical aspects of their physiology and behavior and the long-term effects of these shifts on colony productivity and longevity remain poorly understood. One criticism often leveled at toxicological studies involving honey bees is the use of doses or exposure methods that are not realistically comparable to field-level exposure scenarios (Carreck and Ratnieks 2014). To ensure accuracy in assessments, researchers should strive to base their dose and exposure methods on residue data gathered from field assessments. For IGDs, residues in the part per billion range have been detected in various colony matrices including bee bread and wax (Mullin et al. 2010; Traynor et al. 2016; Tong et al. 2018), though some degradation of the parent compounds is expected to have already occurred at the time of sampling in the referenced studies (Coats 1991). Less is known regarding their presence in matrices like royal jelly, but studies demonstrating effects on queens and larvae following hive feedings suggest that residues can persist.
Based on the literature reviewed here, the most pressing areas to be explored by future studies are those that have the potential to impact honey bee queens and drones and worker behavior, longevity, and performance. For queens, these efforts should involve targeted studies examining how maternal exposure to IGDs affects the abundance and quality of offspring. These studies should be focused on determining what scenarios and levels of exposure are likely to affect queens, what the anticipated effects will be, and their expected duration. This information will help to inform recommendations such as when to consider requeening or whether to allow the colony to recover without intervention.

For workers, much is already known regarding the physiological and behavioral effects of IGDs, but few studies have addressed the long-term consequences of these effects using field-relevant exposure scenarios. Ultimately, efforts to understand how stressors like IGDs affect long-term colony performance should be performed over multiple worker generations. As social insects, perturbations to a colony population can have consequences beyond the initial effects on individuals (Thompson et al. 2007; Perry et al. 2015). These effects are most apparent when colonies lose large proportions of nurse bees to precocious foraging, leading to reduced brood rearing, and a subsequent generation that must somehow compensate for the loss with a smaller population. Research efforts in this area should focus on identifying how IGDs affect honey bee reproduction, physiology, and behavior and attempt to correlate these observations to effects seen in broader longitudinal studies tracking colony performance throughout the entire year under conditions experienced in commercial operations. With these efforts combined, strategies to avoid or ameliorate any potential effects of IGDs could be more readily identified.

\section{ACKNOWLEDGEMENTS}

Thank you to Dr. Gloria Degrandi-Hoffman and Dr. Paul Pratt for their helpful reviews of this manuscript. Mention of trade names or commercial products in this publication is solely for the purpose of providing specific information and does not imply recommendation or endorsement by the US Department of Agriculture. USDA is an equal opportunity provider and employer.

Code availability Not applicable. 


\section{AUTHOR CONTRIBUTION}

JDF conceived the review, and JDF and VC-H participated in the review and interpretation of the literature, critical analysis, and the writing process.

\section{FUNDING}

This research was supported by USDA projects 2030-21000-001-00-D and 2022-21000-018-00D

\section{DATA AVAILABILITY}

Not applicable.

\section{DECLARATIONS}

Ethics approval Not applicable.

Consent to participate Not applicable.

Consent for publication Not applicable

Conflict of interest The authors declare no competing interests.

\section{OPEN ACCESS}

This article is licensed under a Creative Commons Attribution 4.0 International License, which permits use, sharing, adaptation, distribution and reproduction in any medium or format, as long as you give appropriate credit to the original author(s) and the source, provide a link to the Creative Commons licence, and indicate if changes were made. The images or other third party material in this article are included in the article's Creative Commons licence, unless indicated otherwise in a credit line to the material. If material is not included in the article's Creative Commons licence and your intended use is not permitted by statutory regulation or exceeds the permitted use, you will need to obtain permission directly from the copyright holder. To view a copy of this licence, visit http://creativecommons. org/licenses/by/4.0/.

En plus des effets sur le couvain: les effets potentiels des perturbateurs de croissance des insectes sur la santé et la performance à long terme des colonies d'abeilles.
Agrochimique / Apis mellifera / insecticide / diflubenzuron / méthoxyfénozide / hormone juvénile / ecdysone / évaluation des risques.

Nicht nur Effekte auf die Brut: Potentielle Auswirkungen von Insektenwachstumsrhemmern auf die Langzeitgesundheit und Leistung von Honigbienenvölkern.

Agrochemie / Apis mellifera / Insectizide / Diflubenzuron / Methoxyfenozid / Juvenilhormon / Ecdysone / Risikoabschätzung.

\section{REFERENCES}

Ables ET, Hwang GH, Finger DS, et al. (2016) A genetic mosaic screen reveals ecdysone-responsive genes regulating Drosophila oogenesis. G3 Genes. Genom. Genet. 6:2629-2642. https://doi.org/10.1534 /g3.116.028951

Abramson CI, Squire J, Sheridan A, Mulder PG (2004) The effect of insecticides considered harmless to honey bees (Apis mellifera): proboscis conditioning studies by using the insect growth regulators tebufenozide and diflubenzuron. Environ. Entomol. 33:378-388. https://doi.org/10.1603/0046-225X-33.2.378

Ahn K, Xie X, Riddle J, et al. (2012) Effects of long distance transportation on honey bee physiology. https://doi.org/10.1155/2012/193029

Aizen MA, Harder LD (2009) The global stock of domesticated honey bees is growing slower than agricultural demand for pollination. Curr. Biol. 19:915-918. https://doi.org/10.1016/j.cub.2009.03.071

Aizen MA, Garibaldi LA, Cunningham SA, Klein AM (2008) Long-term global trends in crop yield and production reveal no current pollination shortage but increasing pollinator dependency. Curr. Biol. 18:15721575. https://doi.org/10.1016/j.cub.2008.08.066

Amdam GV, Norberg K, Hagen A, Omholt SW (2003) Social exploitation of vitellogenin. Proc. Natl. Acad. Sci. 100:1799-1802. https://doi.org/10.1073 /pnas.0333979100

Amdam GV, Simões ZLP, Hagen A, et al. (2004) Hormonal control of the yolk precursor vitellogenin regulates immune function and longevity in honeybees. Exp. Gerontol. 39:767-773. https://doi.org/10.1016/j. exger.2004.02.010

Amdam GV, Page RE, Fondrk MK, Brent CS (2010) Hormone response to bidirectional selection on social behavior. Evol. Dev. 12:428-436. https://doi. org/10.1111/j.1525-142X.2010.00429.x

Barchuk AR, Bitondi MMG, Simões ZLP (2002) Effects of juvenile hormone and ecdysone on the 
timing of vitellogenin appearance in hemolymph of queen and worker pupae of Apis mellifera. J. Insect Sci. 2:

Barker RJ, Waller GD (1978) Effects of diflubenzuron wettable powder on caged honey bee colonies. Environ. Entomol. 7:534-535. https://doi.org/10.1093 /ee/7.4.534

Benaets K, Van Geystelen A, Cardoen D, et al. (2017) Covert deformed wing virus infections have longterm deleterious effects on honeybee foraging and survival. Proc. Biol. Sci. 284:20162149. https://doi. org/10.1098/rspb.2016.2149

Berenbaum MR, Liao L-H (2019) Honey bees and environmental stress: toxicologic pathology of a superorganism. Toxicol. Pathol. 47:1076-1081. https://doi. org/10.1177/0192623319877154

Bloch G, Hazan E, Rafaeli A (2013) Circadian rhythms and endocrine functions in adult insects. J. Insect Physiol. 59:56-69. https://doi.org/10.1016/j. jinsphys.2012.10.012

Böhme F, Bischoff G, Zebitz CPW, et al. (2018) From field to food-will pesticide-contaminated pollen diet lead to a contamination of royal jelly? Apidologie 49:112119. https://doi.org/10.1007/s13592-017-0533-3

Bordier C, Suchail S, Pioz M, et al. (2017) Stress response in honeybees is associated with changes in task-related physiology and energetic metabolism. J. Insect Physiol. 98:47-54. https://doi.org/10.1016/j. jinsphys.2016.11.013

Brodschneider R, Gray A, Adjlane N, et al. (2018) Multicountry loss rates of honey bee colonies during winter 2016/2017 from the COLOSS survey. J. Apic. Res. $57: 452-457$. https://doi.org/10.1080 /00218839.2018.1460911

Brødsgaard CJ, Ritter W, Hansen H (1998) Response of in vitro reared honey bee larvae to various doses of Paenibacillus larvae larvae spores. Apidologie 29:569-578. https://doi.org/10.1051/apido:19980609

Calderone NW (2012) Insect pollinated crops, insect pollinators and US agriculture: trend analysis of aggregate data for the period 1992-2009. PLoS ONE 7:e37235. https://doi.org/10.1371/journal.pone.0037235

CalDPR (2019) CalPIP Home - California Pesticide Information Portal. In: CalPIP. https://calpip.cdpr.ca. gov/main.cfm. Accessed 11 Feb 2020

Capella ICS, Hartfelder K (1998) Juvenile hormone effect on DNA synthesis and apoptosis in caste-specific differentiation of the larval honey bee (Apis mellifera L. ) ovary. J. Insect Physiol. 44:385-391. https://doi. org/10.1016/S0022-1910(98)00027-4

Carreck NL, Ratnieks FLW (2014) The dose makes the poison: have "field realistic" rates of exposure of bees to neonicotinoid insecticides been overestimated in laboratory studies? J. Apic. Res. 53:607-614. https://doi.org/10.3896/IBRA.1.53.5.08

Cavigli I, Daughenbaugh KF, Martin M, et al. (2016) Pathogen prevalence and abundance in honey bee colonies involved in almond pollination. Apidologie
47:251-266. https://doi.org/10.1007/s13592-0150395-5

Chang L-H, Barron AB, Cheng K (2015) Effects of the juvenile hormone analogue methoprene on rate of behavioural development, foraging performance and navigation in honey bees (Apis mellifera). J. Exp. Biol. 218:1715-1724. https://doi.org/10.1242 /jeb.119198

Chen Y-W, Wu P-S, Yang E-C, et al. (2016) The impact of pyriproxyfen on the development of honey bee (Apis mellifera L. ) colony in field. J. Asia Pac. Entomol. 19:589-594. https://doi.org/10.1016/j. aspen.2016.06.005

Christen V, Kunz PY, Fent K (2018) Endocrine disruption and chronic effects of plant protection products in bees: can we better protect our pollinators? Environ. Pollut. 243:1588-1601. https://doi.org/10.1016/j. envpol.2018.09.117

Claudianos C, Ranson H, Johnson RM, et al. (2006) A deficit of detoxification enzymes: pesticide sensitivity and environmental response in the honeybee. Insect Mol. Biol. 15:615-636. https://doi.org/10.1111 /j.1365-2583.2006.00672.x

Coats JR (1991) Pesticide degradation mechanisms and environmental activation. In: Somasundaram $\mathrm{L}$ and Coats JR (eds.) Pesticide Transformation Products. American Chemical Society, American Chemical Society, Washington DC, pp 10-30

Colin T, Meikle WG, Wu X, Barron AB (2019) Traces of a neonicotinoid induce precocious foraging and reduce foraging performance in honey bees. Environ. Sci. Technol. 53:8252-8261. https://doi.org/10.1021/acs. est.9b02452

Corby-Harris V, Meador CAD, Snyder LA, et al. (2016) Transcriptional, translational, and physiological signatures of undernourished honey bees (Apis mellifera) suggest a role for hormonal factors in hypopharyngeal gland degradation. J. Insect Physiol. 85:65-75. https://doi.org/10.1016/j.jinsphys.2015.11.016

Corby-Harris V, Snyder L, Meador C (2019) Fat body lipolysis connects poor nutrition to hypopharyngeal gland degradation in Apis mellifera. J. Insect Physiol. $116: 1-9$. https://doi.org/10.1016/j. jinsphys.2019.04.001

Corona M, Velarde RA, Remolina S, et al. (2007) Vitellogenin, juvenile hormone, insulin signaling, and queen honey bee longevity. Proc. Natl. Acad. Sci. 104:71287133. https://doi.org/10.1073/pnas.0701909104

Crailsheim K (1992) The flow of jelly within a honeybee colony. J. Comp. Physiol. B. 162:681-689. https://doi. org/10.1007/BF00301617

Cutler G, Scott-Dupree C (2007) Novaluron: prospects and limitations in insect pest management. Pest. Technol. $1: 38-46$

Cutler GC, Scott-Dupree CD, Tolman JH, Harris CR (2005) Acute and sublethal toxicity of novaluron, a novel chitin synthesis inhibitor, to Leptinotarsa decemlineata (Coleoptera: Chrysomelidae). Pest Manag. Sci. 61:1060-1068. https://doi.org/10.1002 /ps.1091 
Davidson EW (1970) Ultrastructure of peritrophic membrane development in larvae of the worker honey bee (Apis mellifera). J. Invertebr. Pathol. 15:451-454. https://doi.org/10.1016/0022-2011(70)90190-4

DeGrandi-Hoffman G, Chen Y, Simonds R (2013) The effects of pesticides on queen rearing and virus titers in honey bees (Apis mellifer a L.). Insects 4:71-89. https://doi.org/10.3390/insects4010071

DeGrandi-Hoffman G, Chen Y, Watkins Dejong E, et al. (2015) Effects of oral exposure to fungicides on honey bee nutrition and virus levels. J. Econ. Entomol. 108:2518-2528. https://doi.org/10.1093/jee/tov251

DeGrandi-Hoffman G, Graham H, Ahumada F, et al. (2019) The economics of honey bee (Hymenoptera: Apidae) management and overwintering strategies for colonies used to pollinate almonds. J. Econ. Entomol. https://doi.org/10.1093/jee/toz213

Derecka K, Blythe MJ, Malla S, et al. (2013) Transient exposure to low levels of insecticide affects metabolic networks of honeybee larvae. PLoS One 8:e68191. https://doi.org/10.1371/journal.pone.0068191

Després L, David J-P, Gallet C (2007) The evolutionary ecology of insect resistance to plant chemicals. Trends Ecol. Evol. 22:298-307. https://doi.org/10.1016/j. tree.2007.02.010

Dhadialla TS, Carlson GR, Le DP (1998) New insecticides with ecdysteroidal and juvenile hormone activity. Annu. Rev. Entomol. 43:545-569. https://doi. org/10.1146/annurev.ento.43.1.545

du Rand EE, Human H, Smit S, et al. (2017) Proteomic and metabolomic analysis reveals rapid and extensive nicotine detoxification ability in honey bee larvae. Insect Biochem. Mol. Biol. 82:41-51. https://doi. org/10.1016/j.ibmb.2017.01.011

Dubrovsky EB (2005) Hormonal cross talk in insect development. Trends Endocrinol. Metab. 16:6-11. https://doi.org/10.1016/j.tem.2004.11.003

Elekonich MM, Jez K, Ross AJ, Robinson GE (2003) Larval juvenile hormone treatment affects pre-adult development, but not adult age at onset of foraging in worker honey bees (Apis mellifera). J. Insect Physiol. 49:359-366. https://doi.org/10.1016/S0022-1910(03 )00020-9

Ellis MB, Nicolson SW, Crewe RM, Dietemann V (2010) Brood comb as a humidity buffer in honeybee nests. Naturwissenschaften 97:429-433. https://doi. org/10.1007/s00114-010-0655-1

Emmett BJ, Archer BM (1980) The toxicity of diflubenzuron to honey bee (Apis mellifera L. ) colonies in apple orchards. Plant Pathol. 29:177-183. https://doi.org/10.1111/j.1365-3059.1980.tb01209.x

Feldlaufer MF, Svoboda JA, Herbert EW (1986) Makisterone A and 24-methylenecholesterol from the ovaries of the honey bee, Apis mellifera L. Experientia 42:200-201. https://doi.org/10.1007/BF01952468

Fernandez FC, Cruz-Landim CD, Malaspina O (2012) Influence of the insecticide pyriproxyfen on the flight muscle differentiation of Apis mellifera
(Hymenoptera, Apidae). Microsc. Res. Tech. 75:844848. https://doi.org/10.1002/jemt.22003

Ffrench-Constant RH, Bass C (2017) Does resistance really carry a fitness cost? Curr Opin Insect Sci 21:39-46. https://doi.org/10.1016/j.cois.2017.04.011

Fine JD (2020) Evaluation and comparison of the effects of three insect growth regulators on honey bee queen oviposition and egg eclosion. Ecotoxicol. Environ. Saf. 05:111142. https://doi.org/10.1016/j. ecoenv.2020.111142

Fine JD, Cox-Foster DL, Mullin CA (2017a) An inert pesticide adjuvant synergizes viral pathogenicity and mortality in money bee larvae. Sci. Rep. 7:1-9. https://doi.org/10.1038/srep40499

Fine JD, Mullin CA, Frazier MT, Reynolds RD (2017b) Field residues and effects of the insect growth regulator novaluron and its major co-formulant $n$-methyl-2-pyrrolidone on honey bee reproduction and development. J. Econ. Entomol. 110:1993-2001. https://doi. org/10.1093/jee/tox 220

Fisher A, Colman C, Hoffmann C, et al. (2018) The effects of the insect growth regulators methoxyfenozide and pyriproxyfen and the acaricide bifenazate on honey bee (Hymenoptera: Apidae) forager survival. J. Econ. Entomol. 111:510-516. https://doi.org/10.1093 /jee/tox 347

Fourrier J, Deschamps M, Droin L, et al. (2015) Larval exposure to the juvenile hormone analog pyriproxyfen disrupts acceptance of and social behavior performance in adult honeybees. PLoS ONE 10:e0132985. https://doi.org/10.1371/journal.pone.0132985

Free JB (1961) Hypopharyngeal gland development and division of labour in honey-bee (Apis mellifera L.) colonies. Proc. R. Entomol. Soc. Lond. Ser. Gen. Entomol. 36:5-8. https://doi.org/10.1111/j.13653032.1961.tb00253.x

Geddes LH, McQuillan HJ, Aiken A, et al. (2013) Steroid hormone (20-hydroxyecdysone) modulates the acquisition of aversive olfactory memories in pollen forager honeybees. Learn. Mem. 20:399-409. https://doi. org/10.1101/1m.030825.113

Gilbert LI, Bollenbacher WE, Granger NA (1980) Insect endocrinology: regulation of endocrine glands, hormone titer, and hormone metabolism. Annu. Rev. Physiol. 42:493-510. https://doi.org/10.1146 /annurev.ph.42.030180.002425

Goblirsch M, Huang ZY, Spivak M (2013) Physiological and behavioral changes in honey bees (Apis mellifera) induced by Nosema ceranae infection. PLoS ONE 8:e58165. https://doi.org/10.1371/journal. pone. 0058165

Goulson D, Nicholls E, Botías C, Rotheray EL (2015) Bee declines driven by combined stress from parasites, pesticides, and lack of flowers. Science 347:1255957. https://doi.org/10.1126/science. 1255957

Grosscurt AC (1978) Diflubenzuron: some aspects of its ovicidal and larvicidal mode of action and an evaluation of its practical possibilities. Pestic. Sci. 9:373-386. https://doi.org/10.1002/ps.2780090502 
Gupta PR, Chandel RS (1995) Effects of diflubenzuron and penfluron on workers of Apis cerana indica F and Apis mellifera L. Apidologie 26:3-10. https://doi. org/10.1051/apido:19950101

Hagedorn HH, Kunkel JG (1979) Vitellogenin and vitellin in insects. Annu. Rev. Entomol. 24:475505. https://doi.org/10.1146/annurev. en.24.010179.002355

Hartfelder K (2000) Insect juvenile hormone: from "status quo" to high society. Braz. J. Med. Biol. Res. 33:157177. https://doi.org/10.1590/S0100-879 X2000000200003

Hartfelder K, Köstlin K, Hepperle C (1995) Ecdysteroiddependent protein synthesis in caste-specific development of the larval honey bee ovary. Rouxs. Arch. Dev. Biol. Off. Organ. EDBO 205:73-80. https://doi. org/10.1007/BF00188845

Henzell RF, Lauren DR, East R (1979) Effect on the egg hatch of white-fringed weevil of feeding lucerne treated with the insect growth regulator diflubenzuron. N. Z. J. Agric. Res. 22:197-200. https://doi.org/10.1080 /00288233.1979.10420861

Herbert EW Jr, Argauer RJ, Shimanuki H (1986) The effect of an insect chitin synthesis inhibitor on honey bees. Apidologie 17:73-76. https://doi.org/10.1051 /apido:19860107

Higes M, Martín-Hernández R, Botías C, et al. (2008) How natural infection by Nosema ceranae causes honeybee colony collapse. Environ. Microbiol. 10:2659-2669. https://doi.org/10.1111/j.1462-2920.2008.01687.x

Hinton HE (1969) Respiratory systems of insect egg shells. Annu. Rev. Entomol. 14:343-368. https://doi. org/10.1146/annurev.en.14.010169.002015

Hodgson EW, Pitts-Singer TL, Barbour JD (2011) Effects of the insect growth regulator, novaluron on immature alfalfa leafcutting bees, Megachile rotundata, J. Insect Sci. 11:43. https://doi.org/10.1673/031.011.0143

Hoffmann KH, Lorenz MW (1998) Recent advances in hormones in insect pest control. Phytoparasitica 26:323-330. https://doi.org/10.1007/BF02981447

Ishimoto H, Kitamoto T (2010) The steroid molting hormone ecdysone regulates sleep in adult Drosophila melanogaster. Genetics 185:269-281. https://doi. org/10.1534/genetics.110.114587

Ishimoto H, Sakai T, Kitamoto T (2009) Ecdysone signaling regulates the formation of long-term courtship memory in adult Drosophila melanogaster. Proc. Natl. Acad. Sci. 106:6381-6386. https://doi. org/10.1073/pnas.0810213106

Jacobs CGC, Rezende GL, Lamers GEM, van der Zee M (2013) The extraembryonic serosa protects the insect egg against desiccation. Proc. R. Soc. B Biol. Sci. 280:20131082. https://doi.org/10.1098 /rspb.2013.1082

Janmaat AF, Winston ML (2000) The influence of pollen storage area and Varroa jacobsoni Oudemans parasitism on temporal caste structure in honey bees (Apis mellifera L. ). Insect. Soc. 47:177-182. https://doi. org/10.1007/PL00001698
Jaycox ER (1976) Behavioral changes in worker honey bees (Apis mellifera L. ) after injection with synthetic juvenile hormone (Hymenoptera: Apidae). J. Kansas Entomol. Soc. 49:165-170

Jaycox ER, Skowronek W, Guynn G (1974) Behavioral changes in worker honey bees (Apis mellifera) induced by injections of a juvenile hormone mimic. Ann. Entomol. Soc. Am. 67:529-534. https://doi. org/10.1093/aesa/67.4.529

Jindra M, Bittova L (2020) The juvenile hormone receptor as a target of juvenoid "insect growth regulators" Arch. Insect Biochem. Physiol. 103:e21615. https://doi. org/10.1002/arch.21615

Johnson RM, Percel EG (2013) Effect of a fungicide and spray adjuvant on queen-rearing success in honey bees (Hymenoptera: Apidae). J. Econ. Entomol. 106:19521957. https://doi.org/10.1603/EC13199

Khoury DS, Myerscough MR, Barron AB (2011) A quantitative model of honey bee colony population dynamics. PLoS ONE 6:. https://doi.org/10.1371/journal. pone.0018491

Kliot A, Ghanim M (2012) Fitness costs associated with insecticide resistance. Pest Manag. Sci. 68:1431-1437. https://doi.org/10.1002/ps.3395

Kulhanek K, Steinhauer N, Rennich K, et al. (2017) A national survey of managed honey bee 2015-2016 annual colony losses in the USA. J. Apic. Res. 56:328-340. https://doi.org/10.1080 /00218839.2017.1344496

Lee KV, Goblirsch M, McDermott E, et al. (2019) Is the brood pattern within a honey bee colony a reliable indicator of queen quality? Insects 10:12. https://doi. org/10.3390/insects 10010012

Mao W, Schuler MA, Berenbaum MR (2017) Disruption of quercetin metabolism by fungicide affects energy production in honey bees (Apis mellifera). Proc. Natl. Acad. Sci. U. S. A. 114:2538-2543. https://doi. org/10.1073/pnas.1614864114

Matsumura F (2010) Studies on the action mechanism of benzoylurea insecticides to inhibit the process of chitin synthesis in insects: a review on the status of research activities in the past, the present and the future prospects. Pestic. Biochem. Physiol. 97:133-139. https://doi.org/10.1016/j.pestbp.2009.10.001

Medina P, Smagghe G, Budia F, et al. (2002) Significance of penetration, excretion, and transovarial uptake to toxicity of three insect growth regulators in predatory lacewing adults. Arch. Insect Biochem. Physiol. 51:91-101. https://doi.org/10.1002/arch.10053

Meikle WG, Corby-Harris V, Carroll MJ, et al. (2019) Exposure to sublethal concentrations of methoxyfenozide disrupts honey bee colony activity and thermoregulation. PLoS ONE 14:e0204635. https://doi.org/10.1371/journal.pone.0204635

Mello TRP, Aleixo AC, Pinheiro DG, et al. (2014) Developmental regulation of ecdysone receptor $(\mathrm{EcR})$ and EcR-controlled gene expression during pharate-adult development of honeybees (Apis mellifera). Front. Genet. 5:445. https://doi.org/10.3389 /fgene.2014.00445 
Merzendorfer H, Zimoch L (2003) Chitin metabolism in insects: structure, function and regulation of chitin synthases and chitinases. J. Exp. Biol. 206:43934412. https://doi.org/10.1242/jeb.00709

Milchreit K, Ruhnke H, Wegener J, Bienefeld K (2016) Effects of an insect growth regulator and a solvent on honeybee (Apis mellifera L.) brood development and queen viability. Ecotoxicology 25:530-537. https://doi.org/10.1007/s10646-0161611-4

Mirth CK, Tang HY, Makohon-Moore SC, et al. (2014) Juvenile hormone regulates body size and perturbs insulin signaling in Drosophila. Proc. Natl. Acad. Sci. 111:7018-7023. https://doi.org/10.1073 /pnas.1313058111

Moffitt HR, Mantey KD, Tamaki G (1983) Effects of chitin-synthesis inhibitors on oviposition by treated adults and on subsequent egg hatch of the codling moth, Cydia pomonella (Lepidoptera: Olethreutidae). Can. Entomol. 115:1659-1662. https://doi. org/10.4039/Ent1151659-12

Moussian B (2019) Chitin: structure, chemistry and biology. In: Yang Q, Fukamizo T (eds) Targeting chitincontaining organisms. Springer, Singapore, pp 5-18

Moussian B, Schwarz H, Bartoszewski S, NüssleinVolhard C (2005) Involvement of chitin in exoskeleton morphogenesis in Drosophila melanogaster. J. Morphol. 264:117-130. https://doi.org/10.1002 /jmor. 10324

Mullin CA, Frazier M, Frazier JL, et al. (2010) High levels of miticides and agrochemicals in North American apiaries: implications for honey bee health. PLoS ONE 5:e9754. https://doi.org/10.1371/journal. pone. 0009754

Mullin CA, Fine JD, Reynolds RD, Frazier MT (2016) Toxicological risks of agrochemical spray adjuvants: organosilicone surfactants may not be safe. Front. Public Health https://doi.org/10.3389/fpubh.2016.00092

Nijhout HF (1998) Insect hormones. Princeton University Press, Princeton, NJ

Page RE, Peng CY-S (2001) Aging and development in social insects with emphasis on the honey bee, Apis mellifera L. Exp. Gerontol. 36:695-711. https://doi. org/10.1016/S0531-5565(00)00236-9

Pandey A, Bloch G (2015) Juvenile hormone and ecdysteroids as major regulators of brain and behavior in bees. Curr Opin Insect Sci 12:26-37. https://doi. org/10.1016/j.cois.2015.09.006

Park YI, Shu S, Ramaswamy SB, Srinivasan A (1998) Mating in Heliothis virescens: transfer of juvenile hormone during copulation by male to female and stimulation of biosynthesis of endogenous juvenile hormone. Arch. Insect Biochem. Physiol. 38:100107. https://doi.org/10.1002/(SICI)1520-6327(1998 )38:2<100::AID-ARCH6>3.0.CO;2-X

Pener MP, Dhadialla TS (2012) Chapter one - an overview of insect growth disruptors; Applied aspects. In: Dhadialla TS (ed.) Advances in insect physiology. Academic Press, Cambridge, MA, pp 1-162
Perry CJ, Søvik E, Myerscough MR, Barron AB (2015) Rapid behavioral maturation accelerates failure of stressed honey bee colonies. Proc. Natl. Acad. Sci. U. S. A. 112:3427-3432. https://doi.org/10.1073 /pnas.1422089112

Pinto LZ, Bitondi MMG, Simões ZLP (2000) Inhibition of vitellogenin synthesis in Apis mellifera workers by a juvenile hormone analogue, pyriproxyfen. J. Insect Physiol. 46:153-160. https://doi.org/10.1016/S00221910(99)00111-0

Pitts-Singer TL, Barbour JD (2017) Effects of residual novaluron on reproduction in alfalfa leafcutting bees, Megachile rotundata $F$. (Megachilidae). Pest Manag. Sci. 73:153-159. https://doi.org/10.1002/ps.4356

Pollinator Stewardship Council (2014) Catch the buzz: huge bee kill in almonds. In: Bee cult. https://www. beeculture.com/catch-the-buzz-huge-bee-kill-in-almonds/. Accessed 14 Apr 2020

Purdy JR (2015) Potential routes of exposure as a foundation for a risk assessment scheme: a conceptual model. Hazards of pesticides to bees. 12th International Symposium of the ICP-PR Bee Protection Group. JuliusKühn-Arch 22-27. [online] https://ojs.openagrar. de/index.php/JKA/article/view/5312. Accessed 15 July 2020

Retnakaran A, Krell P, Feng Q, Arif B (2003) Ecdysone agonists: mechanism and importance in controlling insect pests of agriculture and forestry. Arch. Insect Biochem. Physiol. 54:187-199. https://doi. org/10.1002/arch.10116

Riddiford LM (2012) How does juvenile hormone control insect metamorphosis and reproduction? Gen. Comp. Endocrinol. 179:477-484. https://doi.org/10.1016/j. ygcen.2012.06.001

Robinson GE (1985) Effects of a juvenile hormone analogue on honey bee foraging behaviour and alarm pheromone production. J. Insect Physiol. 31:277282. https://doi.org/10.1016/0022-1910(85)90003-4

Robinson GE (1987) Regulation of honey bee age polyethism by juvenile hormone. Behav. Ecol. Sociobiol. 20:329-338. https://doi.org/10.1007 /BF00300679

Robinson GE, Strambi C, Strambi A, Feldlaufer MF (1991) Comparison of juvenile hormone and ecdysteroid haemolymph titres in adult worker and queen honey bees (Apis mellifera). J. Insect Physiol. 37:929-935. https://doi.org/10.1016 /0022-1910(91)90008-N

Rucker RR, Thurman WN, Burgett M (2012) Honey bee pollination markets and the internalization of reciprocal benefits. Am. J. Agric. Econ. 94:956-977. https://doi.org/10.1093/ajae/aas031

Schmickl T, Karsai I (2017) Resilience of honeybee colonies via common stomach: a model of self-regulation of foraging. PLoS ONE 12:e0188004. https://doi. org/10.1371/journal.pone.0188004

Schulz DJ, Huang Z-Y, Robinson GE (1998) Effects of colony food shortage on behavioral development in honey bees. Behav. Ecol. Sociobiol. 42:295-303. https://doi.org/10.1007/s002650050442 
Seehuus S-C, Norberg K, Krekling T, et al. (2007) Immunogold localization of vitellogenin in the ovaries, hypopharyngeal glands and head fat bodies of honeybee workers, Apis mellifera, J. Insect Sci. 7:1-14. https://doi.org/10.1673/031.007.5201

Shu S, Park YI, Ramaswamy SB, Srinivasan A (1998) Temporal profiles of juvenile hormone titers and egg production in virgin and mated females of Heliothis virescens (Noctuidae). J. Insect Physiol. 44:11111117. https://doi.org/10.1016/S0022-1910(97)001170

Simon AF, Shih C, Mack A, Benzer S (2003) Steroid control of longevity in Drosophila melanogaster. Science 299:1407-1410. https://doi.org/10.1126 /science.1080539

Simone-Finstrom M, Li-Byarlay $\mathrm{H}$, Huang $\mathrm{MH}$, et al. (2016) Migratory management and environmental conditions affect lifespan and oxidative stress in honey bees. Sci. Rep. 6:1-10. https://doi.org/10.1038 /srep32023

Smagghe G (2009) Ecdysone: structures and functions. Springer Science \& Business Media, Berlin

Southwick EE, Southwick L (1992) Estimating the economic value of honey bees (Hymenoptera: Apidae) as agricultural pollinators in the United States. J. Econ. Entomol. 85:621-633. https://doi.org/10.1093 /jee/85.3.621

Spivak M, Mader E, Vaughan M, Euliss NH (2011) The plight of the bees. Environ. Sci. Technol. 45:34-38. https://doi.org/10.1021/es101468w

Sponsler DB, Johnson RM (2017) Mechanistic modeling of pesticide exposure: The missing keystone of honey bee toxicology. Environ. Toxicol. Chem. 36:871-881. https://doi.org/10.1002/etc.3661

Sumner DA, Matthews WA, Medellín-Azuara J, Bradley A (2016) The economic impacts of the California almond industry. Univ Calif Agric Issues Cent 53

Tasei J-N (2001) Effects of insect growth regulators on honey bees and non-Apis bees. A review. Apidologie 32:527-545. https://doi.org/10.1051/apido:2001102

Thompson HM (2003) Behavioural effects of pesticides in bees-their potential for use in risk assessment. Ecotoxicology 12:317-30

Thompson HM, Wilkins S, Battersby AH, et al. (2005) The effects of four insect growth-regulating (IGR) insecticides on honeybee (Apis mellifera L. ) colony development, queen rearing and drone sperm production. Ecotoxicology 14:757-769. https://doi.org/10.1007 /s10646-005-0024-6

Thompson HM, Wilkins S, Battersby AH, et al. (2007) Modelling long-term effects of IGRs on honey bee colonies. Pest Manag. Sci. 63:1081-1084. https://doi. org/10.1002/ps.1457

Tong Z, Duan J, Wu Y, et al. (2018) A survey of multiple pesticide residues in pollen and beebread collected in China. Sci. Total Environ. 640-641:1578-1586. https://doi.org/10.1016/j.scitotenv.2018.04.424

Traynor KS, Pettis JS, Tarpy DR, et al. (2016) In-hive Pesticide exposome: assessing risks to migratory honey bees from in-hive pesticide contamination in the Eastern United States. Sci. Rep. 6:33207. https://doi.org/10.1038/srep33207

Tunaz H, Uygun N (2004) Insect growth regulators for insect pest control. Turk. J. Agric. For. 28:377-387

vanEngelsdorp D, Evans JD, Saegerman C, et al. (2009) Colony collapse disorder: a descriptive study. PLoS ONE 4:e6481. https://doi.org/10.1371/journal. pone. 0006481

vanEngelsdorp D, Tarpy DR, Lengerich EJ, Pettis JS (2013) Idiopathic brood disease syndrome and queen events as precursors of colony mortality in migratory beekeeping operations in the eastern United States. Prev Vet Med 108:225-233. https://doi.org/10.1016/j. prevetmed.2012.08.004

Vannette RL, Mohamed A, Johnson BR (2015) Forager bees (Apis mellifera) highly express immune and detoxification genes in tissues associated with nectar processing. Sci. Rep. https://doi.org/10.1038 /srep 16224

Wade A, Lin C-H, Kurkul C, et al. (2019) Combined toxicity of insecticides and fungicides applied to California almond orchards to honey bee larvae and adults. Insects 10:20. https://doi.org/10.3390 /insects 10010020

Walsh EM, Sweet S, Knap A, et al. (2020) Queen honey bee (Apis mellifera) pheromone and reproductive behavior are affected by pesticide exposure during development. Behav. Ecol. Sociobiol. 74:33. https://doi. org/10.1007/s00265-020-2810-9

Webb TJ, Shu S, Ramaswamy SB, Dorn S (1999) Influence of juvenile hormone and mating on oogenesis and oviposition in the codling moth, Cydia pomonella. Arch. Insect Biochem. Physiol. 41:186-200. https://doi.org/10.1002/(SICI)1520-6327(1999)41 :4<186::AID-ARCH3>3.0.CO;2-S

Wegener J, Huang ZY, Lorenz MW, Bienefeld K (2009) Regulation of hypopharyngeal gland activity and oogenesis in honey bee (Apis mellifera) workers. J. Insect Physiol. 55:716-725. https://doi.org/10.1016/j. jinsphys.2009.05.003

Wegener J, Huang ZY, Lorenz MW, et al. (2013) New insights into the roles of juvenile hormone and ecdysteroids in honey bee reproduction. J. Insect Physiol. 59:655-661. https://doi.org/10.1016/j. jinsphys.2013.04.006

Weir SB (1970) Control of moulting in an insect. Nature 228:580-581. https://doi.org/10.1038/228580a0

Williams CM (1967) Third-generation pesticides. Sci. Am. 217:13-17

Williams GR, Troxler A, Retschnig G, et al. (2015) Neonicotinoid pesticides severely affect honey bee queens. Sci. Rep. 5:1-8. https://doi.org/10.1038 /srep14621

Winkler P, Sieg F, Buttstedt A (2018) Transcriptional control of honey bee (Apis mellifera) major royal jelly proteins by 20 -hydroxyecdysone. Insects $9:$. https://doi.org/10.3390/insects9030122 
Winston ML (1991) The biology of the honey bee. Harvard University Press

Woyciechowski M, Moroń D (2009) Life expectancy and onset of foraging in the honeybee (Apis mellifera). Insect. Soc. 56:193-201. https://doi.org/10.1007 /s00040-009-0012-6

Wright JE (1976) Environmental and toxicological aspects of insect growth regulators. Environ. Health Perspect. $14: 127-132$

Wu JY, Anelli CM, Sheppard WS (2011) Sub-lethal effects of pesticide residues in brood comb on worker honey bee (Apis mellifera) development and longevity. PLoS ONE 6:e14720. https://doi.org/10.1371/journal. pone. 0014720

Xavier Bellés (2005) Reproductive biology of invertebrates, Vol. 12, Part B: Progress in vitellogenesis. CRC Press

Yue D, Nordhoff M, Wieler LH, Genersch E (2008) Fluorescence in situ hybridization (FISH) analysis of the interactions between honeybee larvae and Paenibacillus larvae, the causative agent of American foulbrood of honeybees (Apis mellifera). Environ. Microbiol. 10:1612-1620. https://doi.org/10.1111 /j.1462-2920.2008.01579.x
Zaluski R, Bittarello AC, Vieira JCS, et al. (2020) Modification of the head proteome of nurse honeybees (Apis mellifera ) exposed to field-relevant doses of pesticides. Sci Rep 10. https://doi.org/10.1038/s41598020-59070-8

Zhou X, Riddiford LM (2002) Broad specifies pupal development and mediates the "status quo" action of juvenile hormone on the pupal-adult transformation in Drosophila and Manduca. Dev. Camb. Engl. 129:2259-2269

Zhu X, Zhou S, Huang ZY (2014) Transportation and pollination service increase abundance and prevalence of Nosema ceranae in honey bees (Apis mellifera). J. Apic. Res. 53:469-471. https://doi.org/10.3896 /IBRA.1.53.4.06

Zufelato MS, Bitondi MMG, Simões ZLP, Hartfelder K (2000) The juvenile hormone analog pyriproxyfen affects ecdysteroid-dependent cuticle melanization and shifts the pupal ecdysteroid peak in the honey bee (Apis mellifera). Arthropod. Struct. Dev. 29:111119. https://doi.org/10.1016/S1467-8039(00)00023-2

Publisher's note Springer Nature remains neutral with regard to jurisdictional claims in published maps and institutional affiliations. 